\title{
Source waters for the highly productive Patagonian shelf in the southwestern Atlantic
}

\author{
Hajoon Song ${ }^{a, *}$, John Marshalla ${ }^{a}$ Michael J. Followsa ${ }^{a}$, Stephanie \\ Dutkiewicz $^{\mathrm{a}}$, Gaël Forget ${ }^{\mathrm{a}}$ \\ ${ }^{a}$ Department of Earth, Atmospheric and Planetary Sciences, Massachusetts Institute of \\ Technology, Cambridge
}

\begin{abstract}
Possible nutrient sources and delivery mechanisms for the highly productive Patagonian shelf in the southwest Atlantic are identified. Using a passive tracer adjoint sensitivity experiment, we identify three source waters: waters local to the Patagonian shelf, coastal waters near the Chilean coast and the subsurface waters in the southeast Pacific. We perform a series of forward simulations of a biogeochemical model to investigate the impact of nutrient perturbations in these source regions to productivity on the Patagonian shelf.

Positive nitrate perturbations from local waters have an immediate impact elevating productivity. Iron perturbations local to the shelf, however, do not change productivity because the shelf region is limited by nitrate. Additional nutrient supply from the other source regions lead to increases in productivity. We find that positive nutrient perturbations in subsurface waters in the southeast Pacific results in the largest boost of productivity over the shelf. These source waters are rich in nutrients and upwelled from
\end{abstract}

\footnotetext{
*Corresponding author, Tel. : +1 6172530098

Email address: hajsong@mit.edu (Hajoon Song)
} 
depth where light levels are so low that they cannot be consumed. Finally we identify wintertime intense vertical mixing as the key process which draws nutrients from below $300-500 \mathrm{~m}$ to the surface before being delivered to the shelf.

Keywords: Patagonian Shelf, Nutrient sources, Adjoint sensitivity analysis, Vertical mixing, Southern Ocean

\section{Introduction}

2

The South Atlantic ocean to the east of Patagonia is one of the most biologically productive regions in the global ocean (Bisbal, 1995; Acha et al., 2004; Palma et al., 2008) resulting in a very rich and diverse community (Romero et al., 2006). The high productivity can be clearly seen in observations of chlorophyll-a from space with the maximum near the shelf-break (Rivas et al., 2006; Romero et al., 2006; Machado et al., 2013).

The Patagonian shelf region is a significant sink of atmospheric carbon dioxide $\left(\mathrm{CO}_{2}\right)$. Padín et al. (2010) suggested the Patagonian shelf as the strongest $\mathrm{CO}_{2}$ uptake region in the Atlantic based on a survey between Spain and the Southern Ocean. It is likely one of the most intense sinks per unit area in the global ocean (Bianchi et al., 2005, 2009), with annual uptake rates rivaling those in the subpolar North Atlantic. In particular, the southwest Atlantic appears to be an area where the biological forcing of the $\mathrm{CO}_{2}$ air-sea exchange exceeds that of solubility (Takahashi et al., 2002), implying that vigorous biological activity is largely responsible for net annual uptake of $\mathrm{CO}_{2}$.

High community productivity requires sufficient supply of both macronu- 
trient (e.g. nitrate, nitrite, phosphate and silica) and micronutrient (e.g. iron). Hence, the distribution of the nutrients, their sources and delivery mechanisms are of great interest. Sabatini et al. (2004) explore the zooplankton hotspot in the Grande Bay on the southern Patagonian shelf, and suggest that elevated nutrient levels originate from land, river and runoff from the Magellan and Fuegian Channels, as well as frontal upwelling.

Acha et al. (2004), on the other hand, argue that high levels of chlorophyll biomass found near the shelf break area is associated with nutrient supply by the Malvinas Current. Nutrient-rich subantarctic water flows northward and provides nutrients to the shelf area through various physical processes including eddies and mixing. Romero et al. (2006) also identify the Malvinas Current as a nutrient source supporting high levels of chlorophyll near the shelf break. Additionally, convergence in the bottom boundary layer and subsequent upwelling can supply nutrients to the Patagonian shelf break.

Garcia et al. (2008) analyze sampled nutrients from a cruise in November 2004 along and across the shelf break fronts and argue that macronutrient is supplied from the Malvinas Current through upwelling along the front. They also suggest four mechanisms of iron supply: frontal upwelling delivering subsurface iron in the Malvinas Current to the euphotic zone, tidal mixing that lifts iron in sediment in the shallow shelf area, deposition of dust and influence of iron-rich ground water from remote regions.

Using the data collected from a series cruises along the Patagonian shelf during 2001 and 2003, Paparazzo et al. (2010) show that nitrate is nearly depleted and negatively correlated with chlorophyll in summer, indicating that nitrate is the limiting nutrient on the Patagonian shelf. They further 
identify the decreasing trend of nitrate moving toward the equator along the shelf, which perhaps hints at the source of nitrate. Subantarctic waters with high level of nitrate penetrate onto the shelf through the gap between Tierra del Fuego and the Malvinas Islands and travel equatorward along the shelf. One might then expect nitrate levels to naturally decreases as it is consumed and mixed with surrounding water masses.

These studies reveal the importance of nitrate and iron sources contributing to high productivity over the Patagonian shelf and suggest controlling physical mechanisms on a regional scale. However, it is still unclear how the supply of nutrients is linked to the large scale ocean circulation, particularly upstream of Drake Passage.

In this study, we seek to understand the sources of nutrients and the physical processes of delivery from a large-scale perspective. To explore the origin of the source water we conduct an adjoint model with a passive tracer. The adjoint tracer approach is a powerful tool to identify water sources for a chosen area (see Fukumori et al. (2004); Chhak and Di Lorenzo (2007); Song et al. (2011)). In addition, it underscores the processes responsible for the delivery since it integrates backward in time. Results from the adjoint model simulation are evaluated using a series of forward biogeochemical model simulations with perturbations to the nutrients in the source water regions. The results indicate that vertical mixing is the key process bringing nutrient-rich water to the surface.

Our paper is organized as follows. The description of the adjoint model using a passive tracer and the forward biogeochemical model with nutrient perturbations is given in section 2. Results from these numerical experiments 
are presented in section 3. Section 4 discusses nutrient supply to the region of interest, the spatial patterns of response in productivity and the possible connection between the observed increasing trend of chlorophyll biomass and nutrient supply. We conclude in section 5.

\section{Experimental design}

The numerical experiments are carried out using the Massachusetts Institute of Technology General Circulation Model (MITgcm) (Marshall et al., 1997a,b; Adcroft et al., 1997; Marshall et al., 1998; Adcroft et al., 1999). The global ocean model is configured following Estimating the Circulation and Climate of the Ocean (ECCO version 4) (Forget et al. (2015a), available at http://mit.ecco-group.org/opendap/ecco_for_las/version_4/release1/contents.html). The parameter values for the turbulent transport of geostrophic eddies (Gent and McWilliams, 1990) and isopycnal diffusion (Redi, 1982) are both $850 \mathrm{~m}^{2}$ $\mathrm{s}^{-1}$ which is smaller than that in ECCO version 4 . The vertical diffusivity for tracers is $1 \times 10^{-5} \mathrm{~m}^{2} \mathrm{~s}^{-1}$. The ECCO version 4 initial condition is integrated freely for one year with the normal year Common Ocean-ice Reference Experiments version 2 (CORE-II) surface forcing.

A simple biogeochemical model is coupled to the physical system to simulate the transport of 6 biogeochemical tracers including both micro and macro nutrients (Dutkiewicz et al., 2005; Parekh et al., 2006; Verdy et al., 2007). This biogeochemical model include a representation of the biological uptake of inorganic nutrient $\left(\mathrm{NO}_{3}, \mathrm{Fe}\right)$ as a function of nutrient limitation and light availability. This biological uptake is termed here "community production" as it includes the impact of both primary producers and herbivores 
(see Appendix A). This model was integrated for a long period of time $(>300$ years) along with the global ocean circulation model with the normal year CORE-II surface forcing to get a quasi-equilibrium biogeochemical states for an initial condition.

The adjoint model integrates the sensitivity of a cost function $J$ to model parameters backward in time. It has proven to be a powerful tool in many studies such as heat transport sensitivity (Marotzke et al., 1999), carbon sequestration efficiency (Hill et al., 2004), sensitivity of biological production and air-sea $\mathrm{CO}_{2}$ exchange (Dutkiewicz et al., 2006), ocean circulation and ecosystem in California Current System (Moore et al., 2009), Pacific sardine spawning habitat (Song et al., 2012) and bottom pressure of the Arctic Ocean (Fukumori et al., 2015).

In our study, we define a cost function $J$ as the total amount of passive tracer at the surface over the Patagonian shelf during the last two weeks of the year when the shelf is biologically productive:

$$
J=\int_{T-\Delta t}^{T} \int_{A} C \Delta z d A d t,
$$

where $T$ is December $31^{s t}, \Delta t$ is 2 weeks, $A$ is the size of the area of interest, $C$ is the surface passive tracer concentration which is set to 1 , and $\Delta z$ is the thickness of the model's surface layer. The adjoint model is integrated backward in time for one year to find the source waters of the Patagonian shelf.

We further verify the result from the adjoint experiment with a series of forward integrations of the biogeochemical model. This is prudent because the adjoint model experiment is carried out with passive tracers, and so results do not necessarily apply to biogeochemical variables which experience 
additional sources and sinks. We therefore perturb nutrient concentrations at the source guided by the adjoint and monitor subsequent changes over the Patagonian shelf.

We assume that the size of perturbation in $x_{i}$, the $i^{\text {th }}$ element of the state $\mathbf{x}=\left[x_{1}, x_{2}, \cdots, x_{N}\right]$, is proportional to its contribution to $J$ so that no perturbation is introduced in the regions which do not provide water to the area of interest. A perturbation $\delta x_{i}$ is expressed as

$$
\delta x_{i}=\frac{\partial J / \partial x_{i}}{\sum_{i=1}^{N}\left(\partial J / \partial x_{i}\right)^{2}} \delta J .
$$

We perturb $\mathrm{NO}_{3}$ or $\mathrm{Fe}$ by an amount that would lead to a $10 \%$ increase in $J$ over the area of interest in December. If they are delivered without consumption, we expect the $\mathrm{NO}_{3}$ or Fe levels to increase by $10 \%$ at the Patagonian shelf. A lesser increase would suggest net loss of nutrients along their path. We also monitor the changes in community productivity at the Patagonian shelf and offshore of the shelf break to explore the impact of nutrient perturbations in the water source regions.

After a series of forward experiments in which the initial time was varied, we chose June $1^{\text {st }}$ as the starting date. We also performed additional experiments which started earlier than June, but the responses in the target area were not significantly different. These suggest that the 7 -month forward integration begun on June $1^{s t}$ is long enough to capture most of the physical and biological processes associated with the nutrient delivery and the winter preconditioning of biological activity. 


\section{Results of forward and backward calculations}

\subsection{Simulated biogeochemical ocean states}

The biogeochemical simulation is first evaluated by comparing it with a climatology and with observations (Figure 1). The zonal mean of simulated $\mathrm{NO}_{3}$ generally agrees well with the World Ocean Atlas 2009 climatology in the Southern Ocean (Figure 1(a,b)), showing an increase toward Antarctica and with depth. The simulated Fe is compared with three meridional sections (Figure 1(c-e)). Two meridional sections upstream of Drake Passage show near-depletion at the surface in both observations and model simulations. Fe concentrations increase with depth, and observations and model have similar vertical profiles of Fe when averaged meridionally (Figure 1(c,d)). Fe concentration across the Drake Passage is higher than the other two sections, particularly at the surface of the southern Drake Passage. Along the Drake Passage, the model underestimates Fe concentrations.

Although community productivity cannot be directly compared to chlorophyll concentration, the biological hot spot in the model coincides with areas of high chlorophyll biomass in satellite data (Figure 2). Additionally, the seasonal cycle of community productivity is similar to that of chlorophyll biomass when averaged over the area shown in Figure 2. In this simulation, the community productivity in the shelf regions in the southwestern Atlantic are mostly limited by $\mathrm{NO}_{3}$ (the areas with black dots in Figure 2(b)), whereas community productivity is limited by Fe over most of the Southern Ocean. 


\subsection{Adjoint determination of source waters}

Source waters that arrive over the Patagonian shelf after one year, as determined by the adjoint, are shown in Figure 3. Broadly there are three supply regions: (I) waters local to the Patagonian shelf, (II) the southeast Pacific near the Chilean coast south of $42^{\circ} \mathrm{S}$ and (III) the southeast Pacific subsurface ocean along $55^{\circ} \mathrm{S}$. They are labeled in Figure 2(a). In Region I, the depth of source waters is shallower than $200 \mathrm{~m}$ since here they are over the shelf. In Region II, the source waters are spread over the top $300 \mathrm{~m}$, peaking near $250 \mathrm{~m}$. Region III shows the deepest source, extending below $500 \mathrm{~m}$. It is worth noting that regions south of $60^{\circ} \mathrm{S}$ do not "source" the Patagonian shelf, indicating that nutrient-rich water masses south of the Antarctic Circumpolar Current (ACC) are not involved in fueling productivity on the Patagonian shelf. Instead, nutrient-rich subsurface water to the north of the ACC is implicated.

Using adjoint sensitivity experiments, we can quantify the contribution of source waters to the area of interest (see Appendix B). The contributions of Regions I, II and III to the total passive tracer concentration at the Patagonian shelf, estimated following (B.1), are plotted in Figure 4(a). We also compute the relative contribution of $\mathrm{NO}_{3}$ and $\mathrm{Fe}$ in the source waters after weighting by the adjoint sensitivity, and plot them in Figure 4(b,c), respectively. Region III is the largest contributor (Figure 4(a)), providing nearly half of the total passive tracer to the target area. Figure 4(b) shows that Region III is the largest pool of $\mathrm{NO}_{3}$, contributing twice as much as Region I and II. Region III contains the nutrient rich deep water source (Figure 1(b)), and appears to be the largest supplier of $\mathrm{NO}_{3}$ to the Patagonian shelf. 
On the other hand, the largest Fe pool is Region I contributing almost half of the total Fe (Figure 4(c)). The geography of the Patagonian shelf enables Fe to be delivered to it rather readily from the sediment and atmosphere (both sources are simulated in the model; see Appendix A). Its wide shelf is an excellent source for Fe and there is substantial dust supply from Patagonia. The second largest Fe pool is Region III. In the Southern Ocean, Fe is depleted at the surface but increases with depth. Hence, the deep water source in Region III can also be a potent source of Fe.

\subsection{Forward perturbation experiments}

Perturbations in nutrients are introduced in one water source region at a time on June $1^{\text {st }}, 7$ months prior to the target date, at a concentration such that a $10 \%$ increase can be achieved at the Patagonian shelf if there is no consumption along the path, as described in section 2 .

Perturbations in $\mathrm{NO}_{3}\left(\delta \mathrm{NO}_{3}\right)$ have positive impacts on the $\mathrm{NO}_{3}$ level $\left(\Delta \mathrm{NO}_{3}\right)$ and the community productivity $(\Delta \mathrm{BIO})$ but negative impact on the Fe level $(\Delta \mathrm{Fe})$ over the Patagonian shelf (Figure $5(\mathrm{a}-\mathrm{c}))$. The $\delta \mathrm{NO}_{3}$ in Region I triggers the immediate increase of $\mathrm{NO}_{3}$ by approximately $10 \%$ because Region I encompasses the target area. The $\delta \mathrm{NO}_{3}$ in Region I also has an immediate impact on the community productivity (Figure $5(\mathrm{c})$ ). $\mathrm{NO}_{3}$ is the limiting nutrient on the shelf, hence an additional $\mathrm{NO}_{3}$ enhances the community productivity without delay. $\Delta \mathrm{NO}_{3}$ gradually decreases toward the end of the year as newly introduced $\mathrm{NO}_{3}$ is continuously consumed (Figure $5(\mathrm{a}))$. As a result, $\Delta \mathrm{BIO}$ also has a decreasing trend. The smallest $\Delta \mathrm{NO}_{3}$ in December by $\delta \mathrm{NO}_{3}$ in Region $\mathrm{I}$ is associated with the largest response in the community productivity $(2 \%$ increase in $\Delta \mathrm{BIO})$. This suggests that 
additional $\mathrm{NO}_{3}$ in Region I is the most effective in promoting the community productivity on the shelf. The enhanced community productivity consumes $\mathrm{Fe}$, resulting in a slight decrease in $\Delta \mathrm{Fe}$ in December.

$\delta \mathrm{NO}_{3}$ in Regions II and III, in contrast, slowly increase the level of $\mathrm{NO}_{3}$ and community productivity in the target area (Figure 5(a,c)). Region II and III, upstream of Drake Passage, are distant from the Patagonian shelf and $\delta \mathrm{NO}_{3}$ in those regions initially does not impact the biogeochemistry in the target area. As the water mass with additional $\mathrm{NO}_{3}$ moves to the shelf, $\Delta \mathrm{NO}_{3}$ begins to grow and exceeds the $10 \%$ increase in December, suggesting that $\mathrm{NO}_{3}$ is not heavily consumed before it is delivered to the Patagonian shelf. In December, the community productivity experiences a decreasing trend regardless of the perturbed region, suggesting that the consumption of $\mathrm{NO}_{3}$ is faster than the supply of additional $\mathrm{NO}_{3}$ on the shelf.

Perturbations in $\mathrm{Fe}(\delta \mathrm{Fe})$ influence the $\mathrm{Fe}$ level $(\Delta \mathrm{Fe})$ and the $\Delta \mathrm{BIO}$ over the Patagonian shelf (Figure $5(\mathrm{~d}-\mathrm{f})$ ). The $\Delta \mathrm{Fe}$ is increased by about $10 \%$ stemming from $\delta \mathrm{Fe}$ in Region III, indicating that Fe is hardly consumed along its path (Figure 5(e)). In contrast, $\delta \mathrm{Fe}$ in Region I is almost all consumed, resulting in only a slight increase (1.3\%) after 7 months (Figure 5(e)). The $\delta \mathrm{Fe}$ in Region I has almost no impact on the community productivity on the shelf even in June when additional Fe was introduced (Figure 5(f)). The largest $\Delta \mathrm{BIO}$ over the shelf associated with Fe supply is caused by $\delta \mathrm{Fe}$ in Region III, with Region II also contributing but to a lesser extent. Fe perturbations in Region II and III elevate the community productivity in the Fe-limited area at the southeast corner of the target area. Fe perturbations in Region I remain on the northern shelf where Fe is not the limiting nutrient 
and lead to very little impact on the community productivity (see Figure 7).

Combined perturbations in both $\mathrm{NO}_{3}$ and $\mathrm{Fe}\left(\delta \mathrm{NO}_{3}\right.$ and $\left.\delta \mathrm{Fe}\right)$ result in changes in biogeochemistry on the shelf, and changes are similar to the sum of responses to $\delta \mathrm{NO}_{3}$ and $\delta$ Fe separately (Figure $5(\mathrm{~g}-\mathrm{i})$ ). $\Delta \mathrm{BIO}$ is the largest with both $\delta \mathrm{NO}_{3}$ and $\delta \mathrm{Fe}$ (Figure $5(\mathrm{i})$ ). This is to be expected because adding both nutrients relieves the nutrient limitation regardless of the type. Among water source regions, Region III has the most effect on the community productivity. Perturbations in Region I lead to the smallest increase in the community productivity 7 month later. This is because the additional Fe in Region I does not contribute to productivity but perturbations of both nutrients in Regions II and III can enhance productivity.

\section{Discussion}

\subsection{How do source waters arrive at the Patagonian shelf?}

The largest water source for the Patagonian shelf is Region III, the subsurface southeast Pacific ocean (Figure 4(a)). These waters arrive from a depth of $500 \mathrm{~m}$ or so along $55^{\circ} \mathrm{S}$, and are relatively rich in both $\mathrm{NO}_{3}$ and Fe compared to other sources. They are a prime candidate to power new productivity on the Patagonian shelf. But how can water masses at depth ( $>300 \mathrm{~m}$ ) be drawn to the surface within 7 months?

The Southern Ocean is characterized by persistent upwelling driven by strong westerly winds (Marshall and Speer, 2012). This upwelling is driven by a negative wind stress curl. However, given the value of this curl near the ACC $\left(O\left(10^{-7}\right) \mathrm{N} \mathrm{m}^{-2}\right.$, Chelton et al. (2004)), the upwelling rates are only

$O\left(10^{-1}\right) \mathrm{m} \mathrm{day}^{-1}$, too weak to bring the water at $300 \mathrm{~m}$ to the surface within 
a few months. Furthermore, source waters in Region III are in fact generally located north of the ACC where typically downwelling occurs. The vertical velocity related to the meridional overturning circulation can be estimated as $w=\partial \Psi / \partial y$, where $\Psi$ is the stream function for the residual circulation: the estimated $w$ is even smaller than the wind-driven circulation due to eddy compensation (Karsten and Marshall, 2002; Marshall et al., 2006).

Instead, a time series of adjoint sensitivity clearly shows that wintertime convective mixing is the main mechanism bringing deep waters to the surface (Figure 6). On June $1^{\text {st }}$, source waters are below the mixed layer upstream of the Drake Passage. On August $1^{\text {st }}$, a sharp deepening of the mixed layer occurs resulting in the top $500 \mathrm{~m}$ of the water column becoming well mixed. The observed mixed-layer depth upstream of Drake Passage is found to be $500 \mathrm{~m}$ in winter (Dong et al., 2008; Sallée et al., 2010; Holte et al., 2012; Forget et al., 2015b). It is during this period that source waters can be drawn up to the surface. The mixed layer is still deep on October $1^{\text {st }}$ when Region III waters begin to mix with those of Region II. The majority of the source waters arrive on the Patagonian shelf in December. The mixed layer shallows to less than $100 \mathrm{~m}$ in depth as the upper ocean is stratified in summer.

Wintertime vertical mixing in the Southern Ocean has been highlighted as a key to processes in Subantarctic Mode Water formation (McCartney, 1977; Talley, 1996), subduction of anthropogenic $\mathrm{CO}_{2}$ (Sallée et al., 2012) and light limitation for phytoplankton growth (Mitchell and Holm-Hansen, 1991; Sullivan et al., 1993; Cassar et al., 2011). Wintertime intense vertical mixing is also thought to be responsible for Fe supply to the surface (Tagliabue et al., 
2014). Our results show that community productivity on the shelf begins to respond in October (i.e. in the spring) to the Fe perturbation in Region II and III (Figure 5(b)). This suggests that Fe becomes available to the shelf regions after wintertime intense vertical mixing upstream of Drake Passage.

\subsection{Spatial patterns in the response of community productivity}

The forward perturbation simulations guide us in understanding the biogeochemistry at work in the southwest Atlantic ocean. $\mathrm{NO}_{3}$ perturbations result in an increase in community productivity on the Patagonian shelf where $\mathrm{NO}_{3}$ is the limiting nutrient (Figure $7(\mathrm{a}-\mathrm{c})$ ). In particular, $\mathrm{NO}_{3}$ perturbations in Region I lead to higher levels of community productivity over the northern part of the shelf (Figure $7(\mathrm{a})$ ). In contrast, $\mathrm{NO}_{3}$ perturbations in Regions II and III enhance community productivity on the southern margin of the shelf. Additionally, enhanced $\mathrm{NO}_{3}$ input in Regions II and III shrinks the $\mathrm{NO}_{3}$-limited region over the southern part of shelf (Figure $7(\mathrm{~b}, \mathrm{c})$ ).

The additional Fe introduced in Region I has almost no effect on community productivity over the Patagonian shelf where Fe is not the limiting nutrient (Figure $7(\mathrm{~d})$ ). When more Fe is added in regions with nonzero adjoint sensitivity on the shelf (colored area in Figure 3), the community productivity offshore of the shelf break does not change, indicating that the source waters over the shelf are trapped there. Fe perturbations in Regions II and III also do not increase community productivity in the $\mathrm{NO}_{3}$-limited shelf region. Instead, they promote community productivity offshore (Figure $7(\mathrm{e}, \mathrm{f}))$. Although the increase of community productivity due to Fe is smaller than that due to $\mathrm{NO}_{3}$ over the shelf (Figure $5(\mathrm{c}, \mathrm{f})$ ), the Fe perturbations lead to a larger increase of community productivity integrated over the southwest 
Atlantic. The additional Fe from Region III boosts community productivity by up to $30 \%$. The size of the $\mathrm{NO}_{3}$-limited area extends over most of the Patagonian shelf as more Fe is introduced there.

The combined increase of $\mathrm{NO}_{3}$ and Fe in Region I increase community productivity but only over the northern part of the shelf (Figure $7(\mathrm{~g})$ ), similar to the $\mathrm{NO}_{3}$ perturbation case. The extra $\mathrm{NO}_{3}$ and Fe from Regions II and III enhance productivity over both the shelf and offshore of the shelf break. The enhanced community productivity upstream of Drake Passage indicates where nutrient-rich water is upwelled. Addition of $\mathrm{NO}_{3}$ and $\mathrm{Fe}$ in Region III leads to the greatest enhancement of community productivity in the southwest Atlantic ocean (Figure 7(i)).

\subsection{Increasing trend of chlorophyll biomass}

Rivas et al. (2006) report an increasing trend of the chlorophyll maximum observed from SeaWiFS data during 1998 to 2003 over the Patagonian shelf. They argue that higher nutrient supply together with a more stratified water column is a main driver of the trend. Other studies consistently show an increasing chlorophyll trend offshore of the Patagonian shelf (Gregg et al., 2005; Henson et al., 2010; Vantrepotte and Mèlin, 2011; Siegel et al., 2013; Gregg and Rousseaux, 2014). This increasing trend has been explained in terms of temperature trends (Gregg et al., 2005; Siegel et al., 2013) and trends in the Southern Annular Mode (SAM) (Vantrepotte and Mèlin, 2011).

Our study suggests that nutrient supply to the southwest Atlantic relies on wintertime vertical mixing. If there is a long-term deeper wintertime mixed layer, it is likely that the southwest Atlantic will be more replete with nutrients. Sallée et al. (2010) show that mixed layer depths are largely mod- 
ulated by SAM, and there has been a deepening mixed layer trend upstream of Drake Passage. The deepening of the mixed layer potentially brings more nutrient to the surface which can be subsequently transported to the Patagonian shelf by the ACC. Based upon our findings, community productivity and chlorophyll biomass will also show an increasing trend.

\section{Conclusion}

We have explored how the ocean supplies nutrients to the Patagonian shelf, one of the most productive areas in the global ocean with intense $\mathrm{CO}_{2}$ uptake. Three regions were identified as significant sources: (I) the Patagonian shelf itself, (II) the southeast Pacific near the Chilean coast and (III) the subsurface ocean upstream along the ACC in the Southeast Pacific. Region III was found to be most responsible for providing tracers to the Patagonian shelf.

The northern part of the shelf receives waters from regions local to the shelf. This water mass is rich in Fe but remains on the shelf where macronutrient is limited. Hence, in our calculations, only additional $\mathrm{NO}_{3}$ can enhance the community productivity over the shelf. The source waters for the southern shelf and offshore are found at depth in the southeast Pacific in Region III. In our biogeochemical model, $\mathrm{NO}_{3}$ perturbations applied in that source region results in higher community productivity over the shelf where $\mathrm{NO}_{3}$ is the limiting factor. Fe perturbations on the other hand lead to an increase of community productivity offshore where $\mathrm{Fe}$ is the limiting factor. Our study further shows that intense wintertime vertical mixing is the key process drawing high nutrients from the subsurface of the southeast Pacific to 
the surface and preconditioning nutrient fields to spur biological productivity in the following spring in the southwest Atlantic.

\section{Acknowledgement}

We gratefully acknowledge NSF support of the MOBY project (grant OCE-1048926). The authors would like to thank two anonymous reviewers for valuable comments and suggestions, which significantly improved the manuscript.

Acha, E. M., Mianzan, H. W., R. A. Guerrero, M. F., Bava, J., 2004. Marine fronts at the continental shelves of austral South America: Physical and ecological processes. J. Mar. Syst. 44 (1-2), 83 - 105.

Adcroft, A., C., H., Marshall, J., 1999. A new treatment of the Coriolis terms in C-grid models at both high and low resolutions. Mon. Wea. Rev. 127, 1928-1936.

Adcroft, A., Hill, C., Marshall, J., 1997. Representation of topography by shaved cells in a height coordinate ocean model. Mon. Wea. Rev. 125, $2293-2315$.

Bianchi, A. A., Bianucci, L., Piola, A. R., Pino, D. R., I. Schloss, A. P., Balestrini, C. F., 2005. Vertical stratification and air-sea $\mathrm{CO}_{2}$ fluxes in the Patagonian shelf. J. Geophys. Res. 110, C07003.

Bianchi, A. A., Pino, D. R., Perlender, H. G. I., Osiroff, A. P., Segura, V., Lutz, V., Clara, M. L., Balestrini, C. F., Piola, A. R., 2009. Annual balance and seasonal variability of sea-air $\mathrm{CO}_{2}$ fluxes in the Patagonia Sea: Their 
relationship with fronts and chlorophyll distribution. J. Geophys. Res. 114, C03018.

Bisbal, G. A., 1995. The Southeast South American shelf large marine ecosystem: Evolution and components. Mar. Policy 19 (1), 21 - 38.

Cassar, N., Difiore, P., Barnett, B., Bender, M., Bowie, A., Tilbrook, B., Petrou, K., Westwood, K., Wright, S., Lefevre, D., 2011. The influence of iron and light on net community production in the Subantarctic and Polar Frontal Zones. Biogeosciences 8, 227-237.

Chelton, D. B., Schlax, M. G., Freilich, M. H., Milliff, R. F., 2004. Satellite measurements reveal persistent small-scale features in ocean winds. Science 303 (5660), 978-983.

Chhak, K., Di Lorenzo, E., 2007. Decadal variations in the California Current upwelling cells. Geophys. Res. Lett. 34 (14).

Dong, S., Sprintall, J., Gille, S. T., Talley, L., 2008. Southern Ocean mixedlayer depth from Argo float profiles. J. Geophys. Res. 113, C06013.

Dutkiewicz, S., Follows, M. J., Heimbach, P., Marshall, J., 2006. Controls on ocean productivity and air-sea carbon flux: An adjoint model sensitivity study. Geophys. Res. Lett. 33, L02603.

Dutkiewicz, S., Sokolov, A., Scott, J., Stone, P., 2005. A three-dimensional ocean-seaice-carbon cycle model and its coupling to a two-dimensional atmospheric model: uses in climate change studies. In: Joint Program on the Sci. Policy Global Change. MIT, Cambridge, Mass., Ch. Rep. 122. 
Elrod, V. A., Berelson, W. M., Coale, K. H., Johnson, K. S., 2004. The flux of iron from continental shelf sediments: A missing source for global budgets. Geophys. Res. Lett. 31, L12307.

Forget, G., Campin, J.-M., Heimbach, P., Hill, C. N., Ponte, R. M., Wunsch, C., 2015a. ECCO version 4: an integrated framework for non-linear inverse modeling and global ocean state estimation. Geosci. Model Dev. 8 (5), $3653-3743$.

Forget, G., Ferreira, D., Liang, X., 2015b. On the observability of turbulent transport rates by Argo: supporting evidence from an inversion experiment. Ocean Sci. 12 (3), 1107-1143.

Fukumori, I., Lee, T., Cheng, B., Menemenlis, D., 2004. The origin, pathway, and destination of niño-3 water estimated by a simulated passive tracer and its adjoint. J. Phys. Oceanogr. 34 (3), 582-604.

Fukumori, I., Wang, O., Llovel, W., Fenty, I., Forget, G., 2015. A nearuniform fluctuation of ocean bottom pressure and sea level across the deep ocean basins of the Arctic Ocean and the Nordic Seas. Prog. Oceanogr. $134,152-172$.

Garcia, V. M., Garcia, C. A., Mata, M. M., Pollery, R. C., Piola, A. R., Signorini, S. R., McClain, C. R., Iglesias-Rodriguez, M. D., 2008. Environmental factors controlling the phytoplankton blooms at the patagonia shelf-break in spring. Deep-Sea Res. I 55 (9), 1150-1166.

Gent, P. R., McWilliams, J. C., 1990. Isopycnal mixing in ocean circulation models. J. Phys. Oceanogr. 20, 150-155. 
Gregg, W. W., Casey, N. W., McClain, C. R., 2005. Recent trends in global ocean chlorophyll. Geophys. Res. Lett. 32, L03606.

Gregg, W. W., Rousseaux, C. S., 2014. Decadal trends in global pelagic ocean chlorophyll: A new assessment integrating multiple satellites, in situ data, and models. J. Geophys. Res. Oceans 119, 5921-5933.

Henson, S. A., Sarmiento, J. L., Dunne, J. P., Bopp, L., Lima, I., Doney, S. C., John, J., , Beaulieu, C., 2010. Detection of anthropogenic climate change in satellite records of ocean chlorophyll and productivity. Biogeosciences 7, 621-640.

Hill, C. N., Bugion, V., Follows, M. J., Marshall, J. C., 2004. Evaluating carbon sequestration efficiency in an ocean model using adjoint sensitivity analysis. J. Geophys. Res. 109, C11005.

Holte, J. W., Talley, L. D., Chereskin, T. K., Sloyan, B. M., 2012. The role of air-sea fluxes in Subantarctic Mode Water formation. J. Geophys. Res. 117, C03040.

Ito, T., Parekh, P., Dutkiewicz, S., Follows, M., 2005. The Antarctic Circumpolar Productivity Belt. Geophys. Res. Lett. 32, L13604.

Karsten, R. H., Marshall, J., 2002. Constructing the residual circulation of the ACC from observations. J. Phys. Oceanogr. 32, 3315-3327.

Luo, C., Mahowald, N., Bond, T., Chuang, P. Y., Artaxo, P., Siefert, R., Chen, Y., Schauer, J., 2008. Combustion iron distribution and deposition. Global Biogeochem. Cycles 22, GB1012. 
Machado, I., Barreiro, M., Calliari, D., 2013. Variability of chlorophyll-a in the southwestern atlantic from satellite images: Seasonal cycle and enso influences. Continental Shelf Research 53, 102-109.

Marotzke, J., Giering, R., Zhang, K. Q., Stammer, D., Hill, C., Lee, T., 1999. Construction of the adjoint MIT ocean general circulation model and application to Atlantic heat transport sensitivity. J. Geophys. Res. 104 (C12), 29529-29547.

Marshall, J., Adcroft, A., Hill, C., Perelman, L., Heisey, C., 1997a. A finitevolume, incompressible Navier Stokes model for studies of the ocean on parallel computers. J. Geophysical Res. 102 (C3), 5753-5766.

Marshall, J., Hill, C., Perelman, L., Adcroft, A., 1997b. Hydrostatic, quasihydrostatic, and nonhydrostatic ocean modeling. J. Geophysical Res. 102 (C3), 5733-5752.

Marshall, J., Jones, H., Hill, C., 1998. Efficient ocean modeling using nonhydrostatic algorithms. J. Marine Syst. 18, 115-134.

Marshall, J., Shuckburgh, E., Jones, H., Hill, C., 2006. Estimates and implications of surface eddy diffusivity in the Southern Ocean derived from tracer transport. J. Phys. Oceanogr. 36, 1806-1821.

Marshall, J., Speer, K., 2012. Closure of the meridional overturning circulation through Southern Ocean upwelling. Nat. Geosci. 5, 171-180.

Martin, J. H., Knauer, G. A., Karl, D. M., Broenkow, W. W., 1987. VERTEX: Carbon cycling in the northeast Pacic. Deep Sea Res. A 34 (2A), $267-285$. 
McCartney, M. S., 1977. Subantarctic mode water. In: Angel, M. V. (Ed.), A Voyage of Discovery: George Deacon 70th Anniversary Volume. Pergamon Press, Oxford, pp. 103-119.

Mitchell, B. G., Holm-Hansen, O., 1991. Observations of modeling of the Antartic phytoplankton crop in relation to mixing depth. Deep-Sea Res. Pt. A 38 (8), 981-1007.

Moore, A. M., Arango, H. G., Di Lorenzo, E., Miller, A. J., Cornuelle, B. D., 2009. An adjoint sensitivity analysis of the Southern California Current circulation and ecosystem. J. Phys. Oceanogr. 39 (3), 702-720.

Padín, X. A., Vázquez Rodríguez, M., Castano, M., Velo, A., Alonso Pérez, F., Gago, J., Gilcoto, M., Álvarez, M., Pardo, P. C., de la Paz, M., Ríos, A. F., Pérez, F. F., 2010. Air-sea $\mathrm{CO}_{2}$ fluxes in the Atlantic as measured during boreal spring and autumn. Biogeosciences 7 (5), 1587-1606.

Palma, E. D., Matano, R. P., Piola, A. R., 2008. A numerical study of the Southwestern Atlantic Shelf circulation: Stratified ocean response to local and offshore forcing. J. Geophys. Res. 113, C11010.

Paparazzo, F. E., Bianucci, L., Schloss, I. R., Almandoz, G. O., Solís, M., Esteves, J. L., 2010. Cross-frontal distribution of inorganic nutrients and chlorophyll-a on the Patagonian Continental Shelf of Argentina during summer and fall. Revista de biología marina y oceanografía 45 (1), $107-$ 119.

Parekh, P., Follows, M., Boyle, E., 2004. Modeling the global ocean iron cycle. Global Biogeochem. Cycles 18, GB1002. 
Parekh, P., Follows, M. J., Boyle, E. A., 2005. Decoupling of iron and phosphate in the global ocean. Global Biogeochemical Cycles 19, GB2020.

Parekh, P., Follows, M. J., Dutkiewicz, S., Ito, T., 2006. Physical and biological regulation of the soft tissue carbon pump. Paleoceanography 21, PA3001.

Redi, M. H., 1982. Oceanic isopycnal mixing by coordinate rotation. J. Phys. Oceanogr. 12, 1154-1158.

Rivas, A. L., Dogliotti, A. I., Gagliardini, D. A., 2006. Seasonal variability in satellite-measured surface chlorophyll in the Patagonian Shelf. Cont. Shelf Res. 26 (6), 703-720.

Romero, S. I., Piola, A. R., Charo, M., Garcia, C. A. E., 2006. Chlorophyll-a variability off Patagonia based on SeaWiFS data. J. Geophys. Res. 111, C05021.

Sabatini, M., Reta, R., Matano, R., 2004. Circulation and zooplankton biomass distribution over the southern Patagonian shelf during late summer. Cont. Shelf Res. 24 (12), 1359 - 1373.

Sallée, J.-B., Matear, R. J., Rintoul, S. R., Lenton, A., 2012. Localized subduction of anthropogenic carbon dioxide in the southern hemisphere oceans. Nat. Geosci. 5 (8), 579-584.

Sallée, J. B., Speer, K., Rintoul, S., 2010. Zonally asymmetric response of the Southern Ocean mixed-layer depth to the Southern Annular Mode. Nat. Geosci. 3, 273-279. 
Siegel, D., Behrenfeld, M., Maritorena, S., McClain, C., Antoine, D., Bailey, S., Bontempi, P., Boss, E., Dierssen, H., Doney, S., Jr., R. E., Evans, R., Feldman, G., Fields, E., Franz, B., Kuring, N., Mengelt, C., Nelson, N., Patt, F., Robinson, W., Sarmiento, J., Swan, C., Werdell, P., Westberry, T., Wilding, J., Yoder, J., 2013. Regional to global assessments of phytoplankton dynamics from the SeaWiFS mission. Remote Sens. Environ. $135(0), 77-91$.

Song, H., Miller, A. J., Cornuelle, B. D., Di Lorenzo, E., 2011. Changes in upwelling and its water sources in the california current system driven by different wind forcing. Dyn. Atmos. Oceans 52 (1), 170-191.

Song, H., Miller, A. J., McClatchie, S., Weber, E. D., Nieto, K. M., Checkley, D. M., 2012. Application of a data-assimilation model to variability of Pacific sardine spawning and survivor habitats with ENSO in the California Current System. J. Geophys. Res. Oceans 117, C03009.

Sullivan, C., Arrigo, K., McClain, C., Comiso, J., Firestone, J., 1993. Distributions of phytoplankton blooms in the Southern Ocean. Science 262 (5141), 1832-1837.

Tagliabue, A., Sallée, J.-B., Bowie, A. R., Lévy, M., Swart, S., Boyd, P. W., 2014. Surface-water iron supplies in the Southern Ocean sustained by deep winter mixing. Nat. Geosci. 7, 314-320.

Takahashi, T., Sutherland, S., Sweeney, C., Poisson, A., Metzl, N., Tillbrook, B., Bates, N., Wanninkhof, R., Feely, R., Sabine, C., Olafsson, J., Nojiri, Y., 2002. Global seaair $\mathrm{CO}_{2}$ flux based on climatological surface ocean 
${ }_{538} \quad p \mathrm{CO}_{2}$, and seasonal biological and temperature effects. Deep-Sea Res. II $539 \quad 49,1601-1622$.

540 Talley, L. D., 1996. Antarctic Intermediate Water in the South Atlantic. In: ${ }_{541}$ et al., G. W. (Ed.), The South Atlantic: Present and Past Circulation. 542 Springer, Berlin, pp. 219-238.

543 Vantrepotte, V., Mèlin, F., 2011. Inter-annual variations in the SeaWiFS 544 global chlorophyll a concentration (1997?2007). Deep Sea Res.,Part I 58, $545 \quad 429-441$.

546 Verdy, A., Dutkiewicz, S., Follows, M. J., Marshall, J., Czaja, A., 2007. ${ }_{547}$ Carbon dioxide and oxygen fluxes in the Southern Ocean: Mechanisms of 548 interannual variability. Global Biogeochem. Cycles 21, GB2020. 
Table 1: Parameter names, values and units for the biogeochemical model

\begin{tabular}{|c|c|c|}
\hline Parameter name & Value & Units \\
\hline \multicolumn{3}{|l|}{ Light } \\
\hline Light attenuation coefficient & 0.014 & $\mathrm{~m}^{-1}$ \\
\hline Self-shading coefficient & 0.07 & $\mathrm{~m}^{2} \mathrm{mg}^{-1}$ \\
\hline Photosynthetically active radiation & 0.4 & Nondimensional \\
\hline Half saturation light constant $\left(K_{I}\right)$ & 30 & $\mathrm{~W} \mathrm{~m}^{-2}$ \\
\hline \multicolumn{3}{|l|}{ Community productivity } \\
\hline Maximum consumption rate $(\alpha)$ & 0.33 & $\mu \mathrm{M}$ month $^{-1}$ \\
\hline Half saturation $\mathrm{NO}_{3}$ constant $\left(K_{\mathrm{NO}_{3}}\right)$ & 8 & $\mu \mathrm{M}$ \\
\hline Half saturation Fe constant $\left(K_{\mathrm{Fe}}\right)$ & 0.1 & $\mathrm{nM}$ \\
\hline Fraction of new production to DON pool & 0.67 & Nondimensional \\
\hline Time scale for DON remineralization & 6 & month \\
\hline $\mathrm{N}:$ Fe stoichometry & 0.016 & Nondimensional \\
\hline \multicolumn{3}{|l|}{ Iron } \\
\hline Scavenging rate & $0.2 \times 10^{-7}$ & $\mathrm{~s}^{-1}$ \\
\hline Ratio of sediment Fe to $\mathrm{NO}_{3}$ flux $(\beta)$ & 1.153 & Nondimensional \\
\hline Minimum Fe flux from sediment $\left(F_{F e, 0}\right)$ & 0.001 & $\mathrm{pM} s^{-1}$ \\
\hline
\end{tabular}



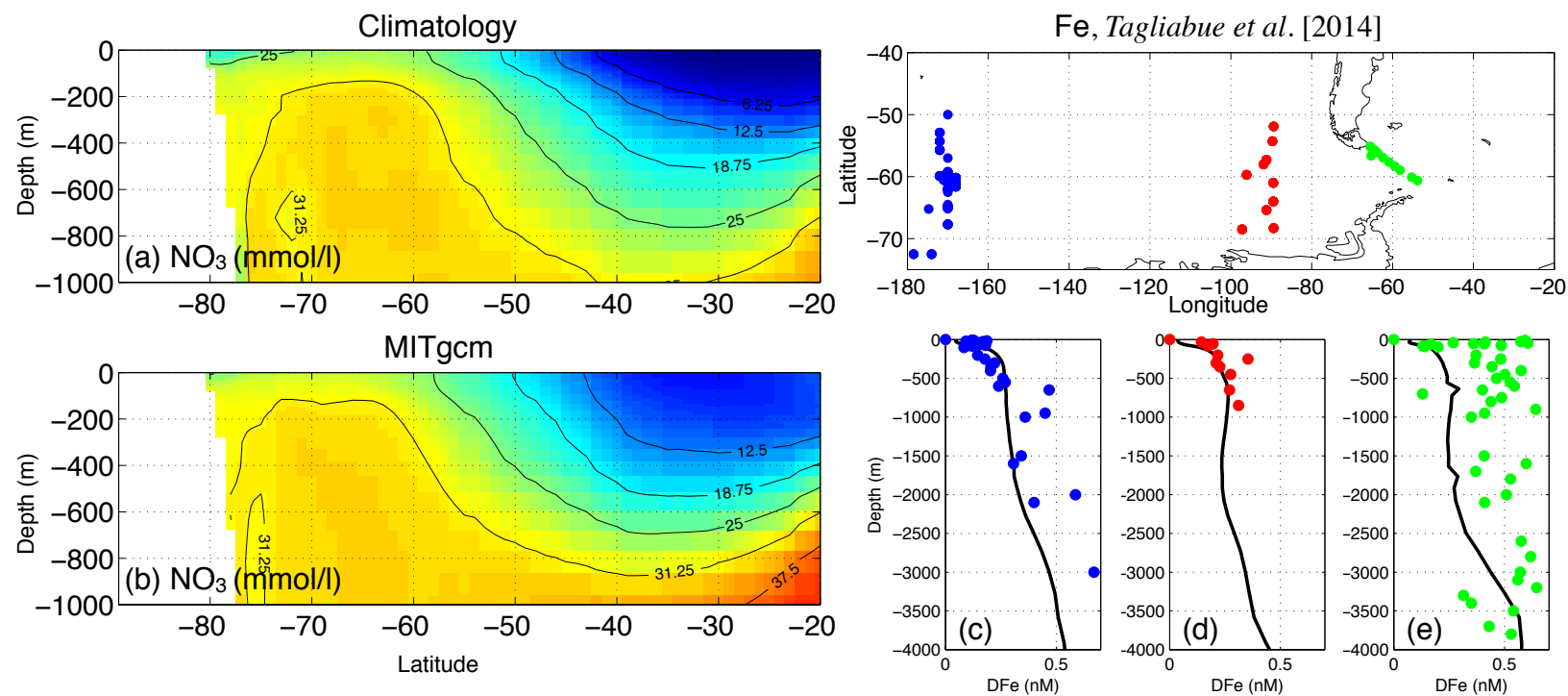

Figure 1: Zonally averaged $\mathrm{NO}_{3}(\mathrm{mmol} / \mathrm{l})$ in the Southern Ocean from the (a) climatology and (b) MITgcm. The simulated iron fields are compared with the observation along three meridional sections: near $170^{\circ} \mathrm{W}$ (blue dots), near $90^{\circ} \mathrm{W}$ (red dots) and the Drake Passage (green dots) as marked in the map. In (c-e), the solid lines represent the iron averaged over the sections in the model and the dots represent the iron observations from Tagliabue et al. (2014). 
(a) SeaWiFS chlorophyll $\left(\mathrm{mg} \mathrm{m}^{-3}\right)$

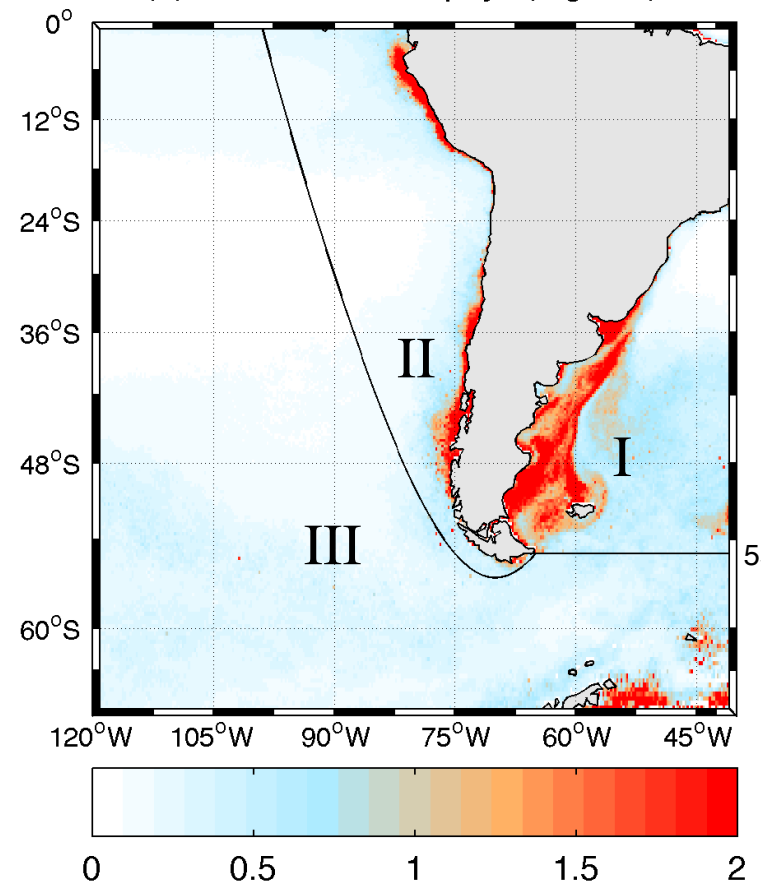

(b) Community produtivity ( $\mathrm{pmol} \mathrm{m} \mathrm{m}^{-3} \mathrm{~s}^{-1}$ )

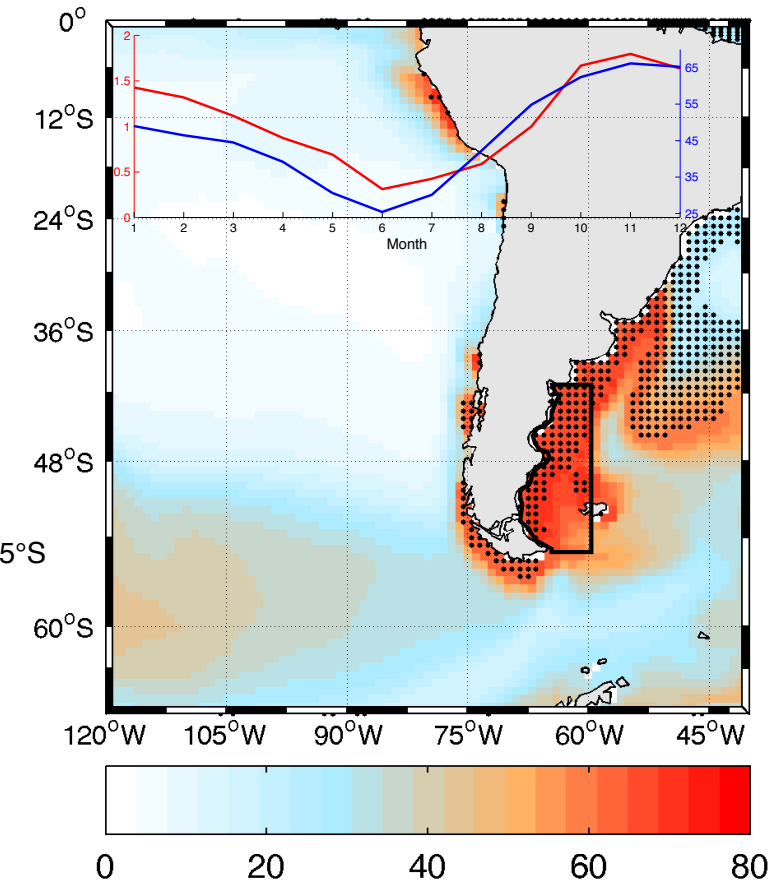

Figure 2: (a) December chlorophyll averaged over 1997-2010 SeaWiFS data and (b) the December-mean simulated community productivity. The area marked with the black line in (b) is the area where the passive tracer is measured in the adjoint calculation. Time series of spatially-averaged chlorophyll (red) and community productivity (blue) in that area are inserted in (b). Three possible source regions are also marked as I, II and III in (a). The areas with black dots in (b) are where $\mathrm{NO}_{3}$ is the limiting nutrient. 


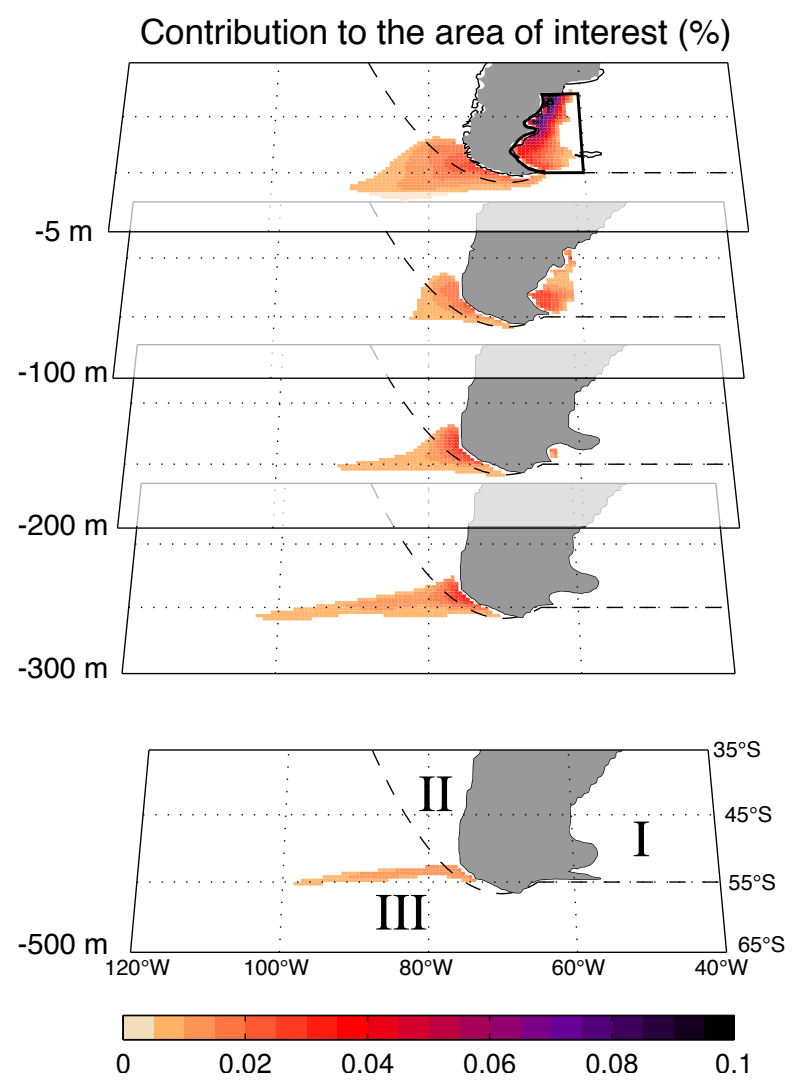

Figure 3: The distribution of source waters one year prior to the arrival in the area of interest (marked with a black solid line) on the Patagonian shelf. The shading represents $r_{i}$, the relative contribution of each grid cell to the cost function change (See Equation (B.2)). Grid cells with contributions less than $10^{-3} \%$ are in white. Sums of all contributions from grid cells is $100 \%$, although the maximum contribution is $O\left(10^{-1}\right)$. Black dashed lines mark the boundaries between Regions I, II and III. 
(a) PTR

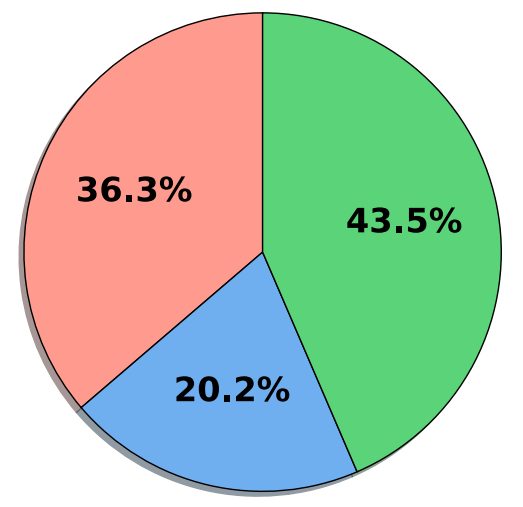

(b) $\mathrm{NO}_{3}$

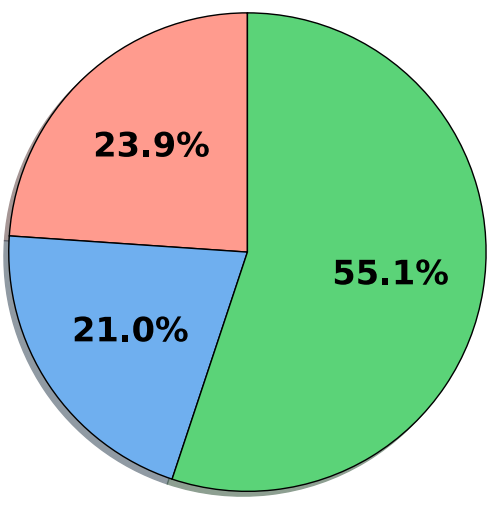

Region I (c) $\mathrm{Fe}$

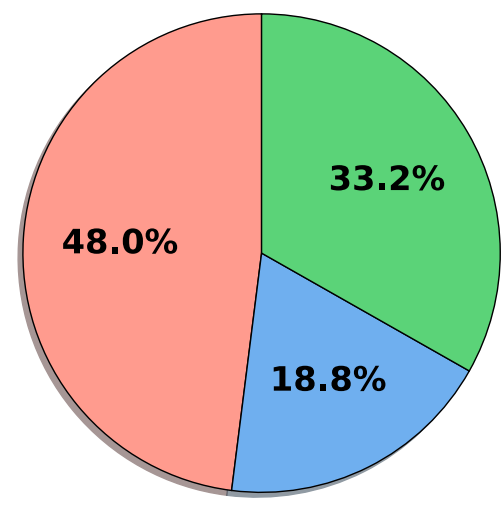

Region II

Region III

Figure 4: (a) The relative passive tracer (PTR) contributions of region I (salmon), II (blue) and III (green) to the Patagonian shelf one year prior to arrival. The percentage of (b) $\mathrm{NO}_{3}$ and (c) Fe at the source regions whose contribution is greater than $10^{-3} \%$ are also computed after weighting these variables by adjoint sensitivity. 
(a) $\Delta \mathrm{NO}_{3}$ to $\delta \mathrm{NO}_{3}$
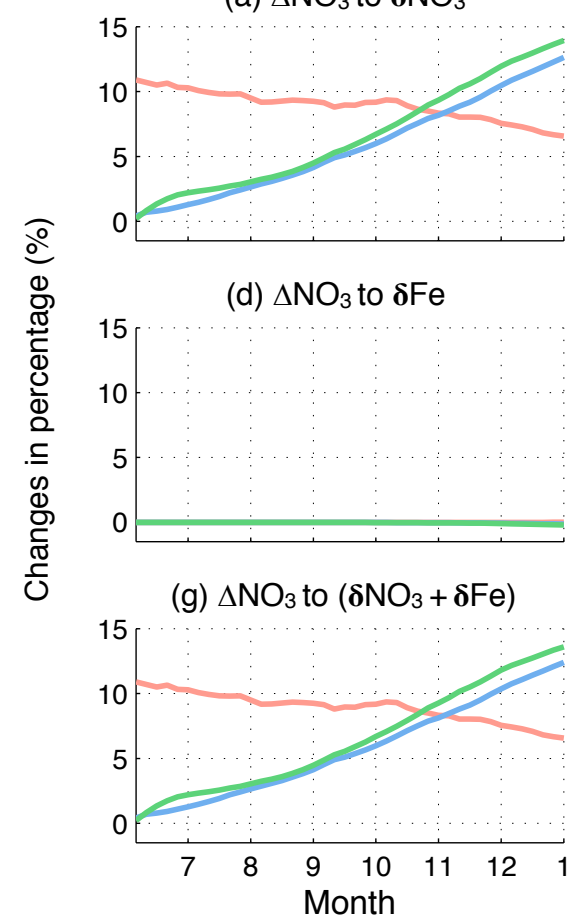

(b) $\Delta \mathrm{Fe}$ to $\delta \mathrm{NO}_{3}$

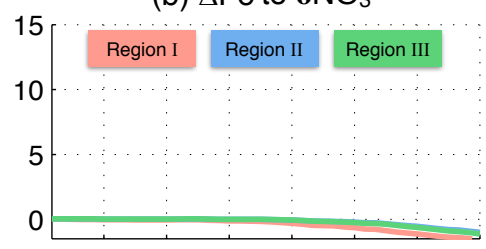

(e) $\Delta \mathrm{Fe}$ to $\delta \mathrm{Fe}$

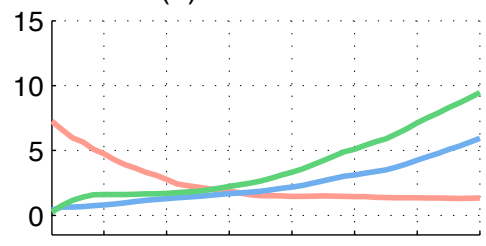

(h) $\Delta \mathrm{Fe}$ to $\left(\boldsymbol{\delta} \mathrm{NO}_{3}+\delta \mathrm{Fe}\right)$

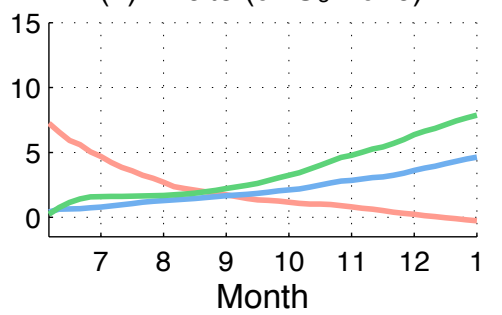

(c) $\triangle \mathrm{BIO}$ to $\delta \mathrm{NO}_{3}$

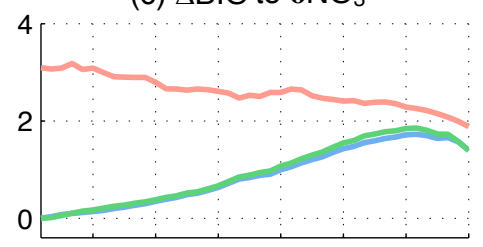

(f) $\triangle \mathrm{BIO}$ to $\delta \mathrm{Fe}$

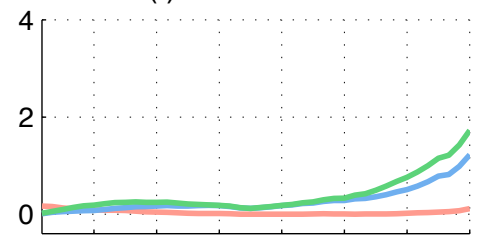

(i) $\triangle \mathrm{BIO}$ to $\left(\delta \mathrm{NO}_{3}+\delta \mathrm{Fe}\right)$

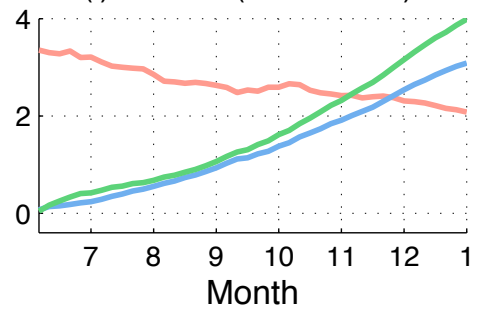

Figure 5: Time series of the changes $(\%)$ in $\mathrm{NO}_{3}, \mathrm{Fe}$ and community productivity $\left(\Delta \mathrm{NO}_{3}\right.$, $\Delta \mathrm{Fe}$ and $\Delta \mathrm{BIO}$, respectively) at the target area to the perturbations of $\mathrm{NO}_{3}\left(\delta \mathrm{NO}_{3}\right), \mathrm{Fe}$ $(\delta \mathrm{Fe})$ and both nutrients introduced in Region I (salmon), II (blue) and III (green) on June $1^{\text {st }}$. 
(a) Source regions on $6 / 1$

(b) Source regions on $8 / 1$

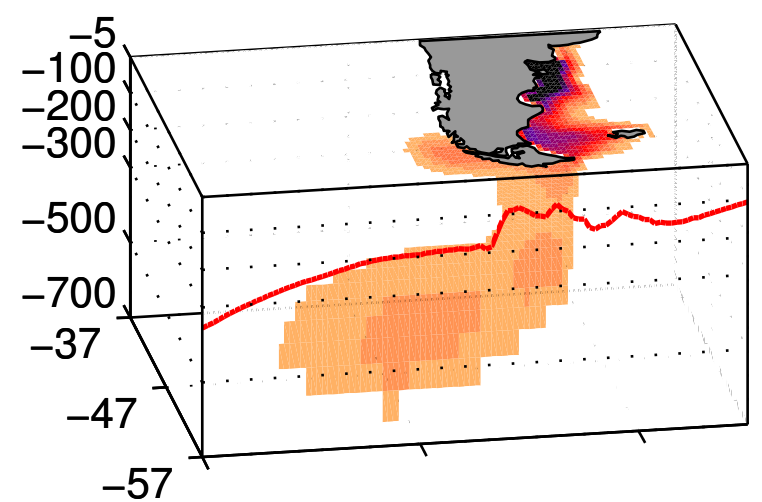

(c) Source regions on 10/1

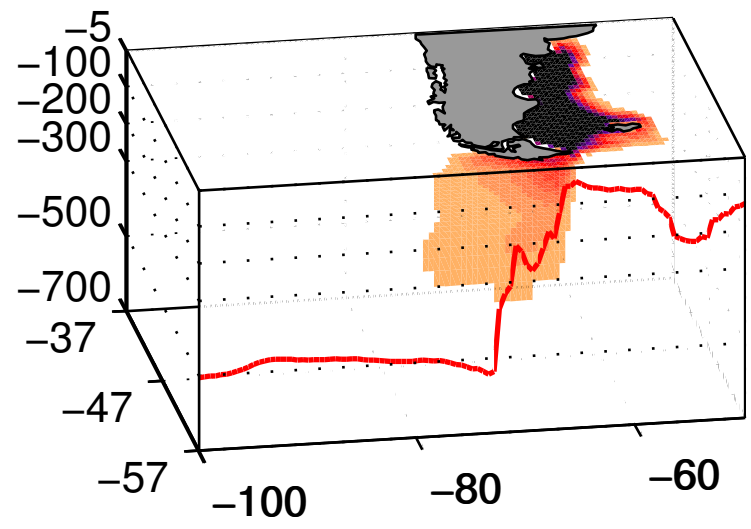

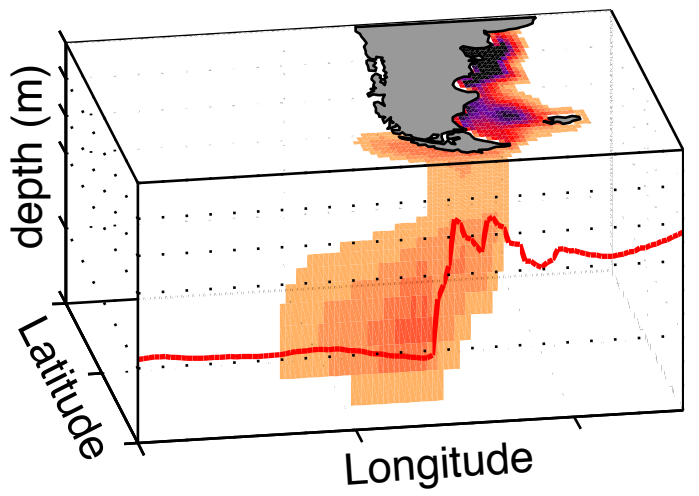

(d) Source regions on $12 / 1$

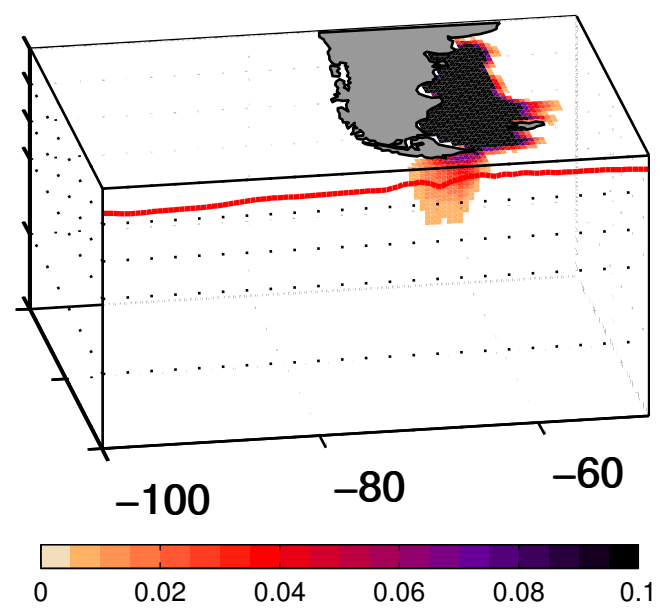

Figure 6: Source waters (shaded) and mixed layer depth (red line) on (a) 6/1 or 7 months before, (b) 8/1 or 5 months before, (c) 10/1 or 3 months before and (d) 12/1 or 1 month before. The shading is the relative contribution as defined in (B.2) 


\section{Region I}
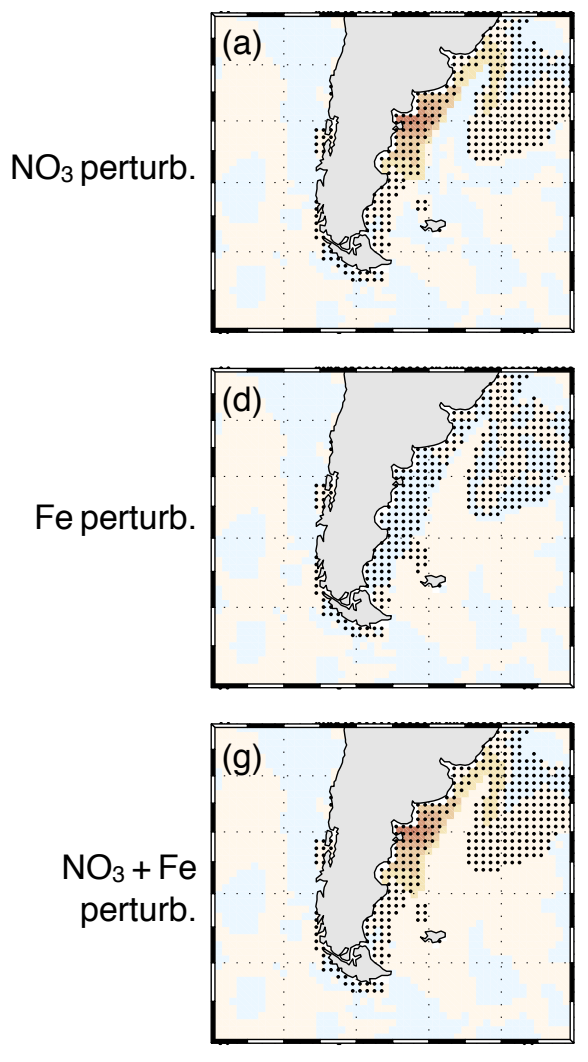

Region II
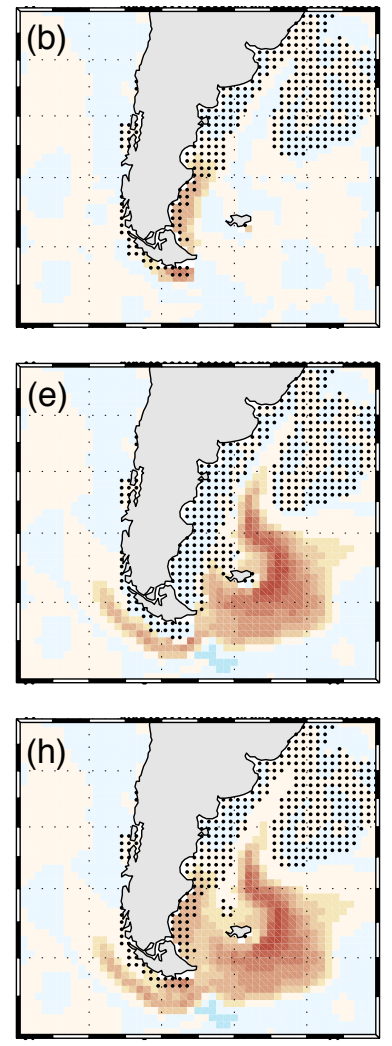

Region III
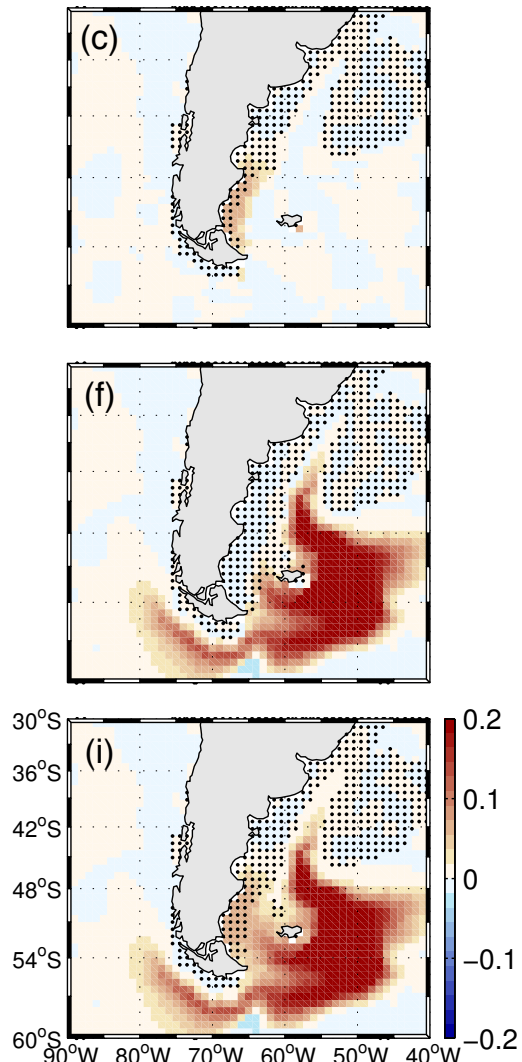

Figure 7: Changes of the community productivity to the perturbations in (a-c) $\mathrm{NO}_{3}$, (d-f) Fe and $(\mathrm{g}-\mathrm{i})$ both nutrients $(0.1=10 \%)$. Perturbations are introduced in Region $(\mathrm{a}, \mathrm{d}, \mathrm{g})$ I, (b,e,h) II and (c,f,i) III on June $1^{\text {st }}$, or 7 months prior to the time when the responses are calculated. Black dots represent the region with $\mathrm{NO}_{3}$ limitation. 